\title{
Velvyslankyně českého undergroundu
}

Machovec, Martin: Writing Underground. Reflections on Samizdat Literature in Totalitarian Czechoslovakia. Praha: Karolinum, 2019. 252 s.

Martin Machovec, pohybující se svými osobními i profesními zájmy již mnoho let mezi dvěma diskurzy, akademickým prostředím a světem undergroundu, odpovídá v roce 2018 na otázku po sepsání Dějin českého undergroundu uměřenými slovy: „Na syntetizující práci tohoto typu je ještě brzy. Snad lze očekávat, že jednotlivé sondy od literárních historiků nebo historiků kultury postupně vytvoří určitou mozaiku." $V$ té době už přitom nepochybně pomýšlí na vydání vlastních studií z let 2001-2018, které svým uspořádáním ve výbor právě takovou mozaiku utvářejí. Publikovaný výbor ze studií s názvem Writing Underground. Reflections on Samizdat Literature in Totalitarian Czechoslovakia (Karolinum 2019) je nejen podstatným př́íspěvkem k českým dějinám literatury (vztahuje se k nim již v názvu), ale výběrem jazyka míří na ještě vyšší metu, totiž zasadit český underground do kontextu světové literatury.

Záměr učinit osvětu českému undergroundu v zahraničí prosvítá jak z četných „žehrajících“ narážek na nedocenění jistých autorů např́ič studiemi, tak z doslovu, v němž Machovec shrnuje nepříznivou situaci „malé české literární scény“ následovně: „Současná česká scéna je malá, zvláště ve srovnání s literární scénou anglicky mluvícího světa, a nebýt Václava Havla, Bohumila Hrabala a Milana Kundery [...], byla by ve Velké Británii, USA či dalších anglicky mluvících zemích pravděpodobně naprosto neznámá“ (s. 237, překlad autorky). Navzdory tomuto a dalším podobným konstatováním, jak autor doplňuje, vyšla v poslední dekádě řada publikací zásadního významu, a to jak v angličtině, tak $\mathrm{v}$ češtině, které pomáhají objasnit postavení a roli českého disentu a kulturního undergroundu. Tyto nejnovější výzkumy v dané oblasti Machovec nepřehlíží, naopak jimi rozšiřuje vlastní výklad, a ačkoli by si možná zasloužily alespoň letmou kritickou konfrontaci, jsou aktualizovány pomocí poznámek pod čarou a vyčerpávající rešeršní přílohou vybrané bibliografie, diskografie a filmografie. 
Výsledkem takové práce je mimo jiné výbor s nepřehlédnutelně bohatou sekundární literaturou a poznámkovým aparátem, který již na první straně dalece přesahuje rozsah textu hlavního.

Koncepce sestává $\mathrm{z}$ deseti studií, $\mathrm{z}$ nichž pět bylo původně psaných $\mathrm{v}$ češtině a dodatečně přeloženo. Za jakým účelem, případně k jaké příležitosti byla každá napsána, objasňuje autor obšírně v ediční poznámce $\mathrm{v}$ závěru knihy, přičemž pouze čtyři z nich shledává seriózními příspěvky $\mathrm{k}$ dějinám literatury či textologii. Pětice dalších představovala původně přednášky, jejichž ustrojení vyžaduje spíše stručnost a nikterak rozsáhlé poznámky pod čarou. Solitérem je v tomto ohledu studie devátá, původně doslov k anglickému vydání básnické sbírky I. M. Jirouse. Tuto přiznanou nekonzistentnost však vyvažuje šíře záběru zkoumaného materiálu, díky níž je umožněno sledovat umělce a jejich tvorbu $\mathrm{v}$ historicko-kulturním kontextu a která vyhovuje povaze undergroundu jako fenoménu vše-uměleckému a společenskému (autor si pro něj vhodně vypůjčuje termín „Gesamtkunstwerk“, když mluví o unikátnosti a neopakovatelnosti undergroundových performancí). Pečlivým výběrem studií, jejich revizí a závěrečným uspořádáním do jednoho výboru se tak Martinu Machovcovi podařilo podat přesvědčivý obraz českého undergroundu od počátku padesátých let až po nedávnou současnost.

Pokud bych se měla zaměřit na míru odbornosti výkladu, mám při hodnocení na paměti tu čtenářskou obec, jíž byla publikace s největší pravděpodobností adresována. Vychází-li autor z předpokladu, že český underground dosud není v zahraničí dostatečně znám ani ceněn, a má-li ambice představit jeho nejrůznorodější fasety, měl by jej umět vyličit poutavě a zároveň kriticky, a to i s ohledem na možnost, že se čtenář s určitými fakty seznamuje poprvé. Zhostit se takového úkolu by mohlo být v mnoha směrech obtížné. Je proto velkým kladem, že undergroundu tu věnuje pozornost odborník, jehož k objektu jeho zájmu pojí i osobní vazby: člověk, který se z nadšence, šiřitele strojopisů a vydavatele samizdatových edic postupně stal jeho předním teoretickým představitelem. To, že Martin Machovec píše takříkajíc $z$ vlastního kruhu, s sebou může přinášet jisté úskalí, o němž se později zmíním; při líčení atmosféry doby a společenských konexí se to naopak ukazuje jako velký benefit.

Domnívám se, že autor takové publikace by měl také vždy podat vysvětlení, vyskytne-li se ve výkladu poprvé určitý jev, který by cizímu publiku nemusel být znám. Proto například Machovec vyjmenovává členy Skupiny 42 stejně jako členy méně známé skupiny umělců „Křižovnické školy“, do poznámky pod čarou přidává obsáhlejší komentář a související prameny k záběhlické surrealis- 
tické skupině, později nazývané Libeňští psychici, apod. V rozsáhlých výčtech, explikacích a neméně hutných poznámkách pod čarou se asi nejzdařileji projevuje autorova snaha čtenáře poučit a nespoléhat předem na jeho obeznámenost s vykládanými fakty. Jediným nedostatkem v tomto směru bylo snad jen ponechání Gruntorádovy knihovny Libri prohibiti bez očekávaného vysvětlení. K hlubšímu pochopení zajisté přispívá i fakt, že zásadní události undergroundu jsou téměř v každé studii znovu vzpomenuty, takže si je i dříve nepoučený čtenář v průběhu četby brzy osvojí. Obecně se dá říci, že koncepce výboru postavená na vybraných sondách utváří dosti srozumitelný rámec, v němž se čtenář zejména díky četným a opakovaným explikacím dobře orientuje.

Abych metodu výkladu ukázala na reprezentativním příkladě, zvolila jsem pátou studii s názvem The Theme of 'Apocalypse' as a Key Building Block of Underground Literature During the Period of 'Normalization'. Zpočátku je v základních obrysech vykresleno prostředí a postavy undergroundové literatury v normalizačním Československu. Stranou není ponechán výklad významu „normalizace“, jejíž represivní projevy celkem podle očekávání podnítily v autorech potřebu aktualizovat právě motiv „zkázy“, prrípadně „apokalypsy“ v širším slova smyslu. Jak autor podotýká, právě tyto drobné postřehy z roviny spíše psychologicko-sociologické než literárně-historické je třeba mít na paměti, chceme-li adekvátně interpretovat zejména literaturu undergroundu z let sedmdesátých. Z Machovcova sugestivního líčení prorežimní doby je navíc zřejmé, že i on sám musel být normalizací nějakým způsobem zasažen, což je pochopitelné, vyrůstal-li autor v prostředí undergroundu - narážím například na přívlastky „loutková vláda“ (s. 85) či „idiotská intolerance“ (s. 30) ve spojení s normalizační érou, užívání uvozovek pro ironicky míněná sousloví typu „obrodný, ,demokratizační proces“(s. 86) apod.; nemohu se však zároveň zbavit lehké pochybnosti, postřehne-li tuto ironicko-kritickou rovinu také zahraniční čtenář. Trest' studie pak představuje poměrně důkladná interpretace motivů zkázy, zmaru, beznaděje, př́ípadně sebedestrukce či alespoň rozvratu a úpadku v poetikách jednotlivých autorů. Nevyužitým potenciálem se mi v tomto ohledu jeví poněkud zkratkovitá čtyřřádková synopse tvorby Jáchyma Topola, jehož román Sestra (přeložený do angličtiny, němčiny, polštiny, slovinštiny, mad'arštiny a těšící se značnému kritickému ohlasu) by jako materiál zkoumání apokalyptických motivů posloužil více než uspokojivě.

Zdá se, že pro styl Machovcova výkladu není určující ani tak podat výčet autorů a jejich děl, která $s$ tímto zastřešujícím motivem apokalypsy nějakým způsobem nakládají, jako spíš dobrat se $\mathrm{k}$ jeho nuancím v poetikách jednotlivých autorů - 
čili zpřesnit, jaké povahy u nich tento motiv nabývá (v případě Bondyho tak např́klad jde o „radostnou sebedestrukci“/s. 60/, Jirousova spirituální poezie sycená křestanstvím zase apokalypsu ve smyslu náhlé ontologické změny dané všeobecnou zkázou zcela odmítá, v Zajíčkově rané tvorbě jsou reflektovány utopické, ale zároveň radostné vize světa atp.). Další užitečnou metodou přispívající ke specifikaci je konfrontace těchto motivů na pozadí křestanské nauky, která odkrývá dva př́iznačné rysy undergroundu: „[...] Křestanská apokalyptika a eschatologie ožívala $\mathrm{v}$ dějinách vícekrát a občas byly z ní čerpané inspirace užívané $\mathrm{k}$ dosti př̀kvapivým účelům, avšak u českých undergroundových autorů jsou tyto reminiscence vesměs vyvažovány silnou dávkou ironie a sebeironie, které se ostatně řadí $\mathrm{k}$ dalším konstantám undergroundové literatury jakožto celku“ (s. 93). Tyto spolu s dalšími jedinečnými „post-apokalyptickými“ motivy jsou podle autora zřejmě nejosobitějším přínosem českého undergroundového ghetta české literatuře. Na tomto ukázkovém komentáři jedné ze studií vidíme, jak dílčí závěry autorovi dovolují učinit konkluze obecnější platnosti.

Současně si můžeme povšimnout, že důraz je kladen především na jedinečnost českého undergroundu, což vnímám jako největší přínos takto sestavené publikace. Vyzdvihuje nejen význam jednotlivců, kteři byli s undergroundem neodmyslitelně spjati (nejzvučnějšími jmény je dvojice Bondy a Jirous), ale všímá si rovněž, čím je ve světovém kontextu český underground unikátní jako takový. Jedním z takových atributů české podzemní kultury může být kupříkladu „mimořádná spolupráce ,rockových primitivi̊ na jedné straně a umělců a intelektuálů na straně druhé. To byl zcela ojedinělý jev [...]“ (s. 30). Tímto prizmatem je zhodnocena básnická tvorba Egona Bondyho, jejíž mimořádnost je spatřována v tom, že „předjímá veškerou poetiku osvobozenou od patosu, totiž americký pop-art a hyperrealismus“ (s. 12). Jelikož Machovec nezasazuje zkoumanou problematiku pouze do kontextu českého a světového, ale také do životních událostí tvưrců, nezřídka může čtenář shledat zajímavým i rozkrývání umělcovy biografie, jako třeba líčení Bondyho počínajícího přátelství s Vodsed'álkem a vzniku jejich společného debutu nebo Jirousových univerzitních let, kdy začíná publikovat. Důvěrná obeznámenost $s$ undergroundovým prostředím konečně autorovi dovolila podělit se i o fakta skrytější povahy. Skutečnost, že si Jirous v době valdického věznění musel vlastní básně memorovat, nebo, při větším štěstí, psát na průklepový papír skládaný do motáku velmi drobného rozměru, není už snad ničím objevným; nadto však Machovec domýšlí, jak tento zdánlivý hendikep podobu jeho poezie tvaroval: „zvláště pak jejich převládající pravidelný rytmus a rýmová schémata, usnadňující autorovi zapamatování“ (s. 182). Jinou takovou pozoruhodností, 
tentokrát ovšem v negativním slova smyslu, je Bondyho epizoda s Chartou 77, kterou sice podepsal, ale později se k tomuto aktu již nehlásil a Chartu dokonce poměrně nevybíravě kritizoval. Originalitu Machovec dokáže rozkrýt i v poetikách spisovatelů - je až s podivem, jaké konotace nalézá v Placákově Manifestu Českých dětí: v ní obsažené reminiscence na myšlenky Duchampovy, Rygullovy, Bondyho a Jirouse slouží podle něj jako „nepřímý důkaz originality myšlenek, jinak dosud opomíjených a ignorovaných, jež byly v undergroundových komunitách utvářeny" (s. 84). Klíčovou úlohu při utváření undergroundové komunity pochopitelně sehrály hudební skupiny. Performance kapely Aktual vysvětluje autor na pozadí světového minimalismu a konkrétní hudby; skupinu DG 307 zase vsazuje do zázemí světového art rocku pro její extraordinární instrumentaci a ambiciózní přístup k provedení skladeb. Jejich přínos autor souhrnně spatřuje ve schopnosti dovést až na samou hranici spontánnost, nevinnost nebo naivitu a osobitou performancí je překonat. Příznivým zhodnocením nejrozmanitějších projevi̊ undergroundu se autorovi daří vyhranit se vůči výtce, že byl jen „nálepkou pro určitý životní styl“" (s. 65).

Nabízí se otázka, zda se při tak rozbíhavém záběru naopak dočteme také nějaké definice undergroundu. Až na opakovaně citovaný výňatek z Jirousovy Zprávy o třetím českém hudebním obrození (viz např. s. 36), který by se za takovou formulaci zřejmě považovat dal, spíš než definován je underground vymezován na proměnlivém pozadí: underground vs. sekta, underground vs. křestanství, underground jako výhradně hudební fenomén, underground v kontextu normalizační doby apod. Tímto prostřednictvím Machovec - třebaže implicitně definici undergroundu např́č studiemi obkružuje, a tím zároveň zpřesňuje.

Konfrontuje-li underground s hnutím New Age, pak proto, aby našel jednu, dvě spojnice, přispívající k pochopení toho, jak Machovec underground vnímá. Jinde jej zase vnímá v kontrastu k signatár̆ům Charty 77 a v závěru vypoví něco specifického o obou. Přibližuje jej také k existencialismu, duchovnímu klimatu doby. Výklad tak může připomenout cosi na způsob manter, slovních spojení, $\mathrm{k}$ nimž se badatel stále dokola navrací a které nabývají na významu právě díky opakování. (Postačí srovnat „definici“ undergroundu předloženou na s. 34 s obdobnou „definicí“ na s. 38. Zatímco v první z nich je undergroundová komunita nahlížena jako „pluralitní otevřené společenství, usilující o udržení a další rozvoj nezcizených, autentických hodnot“, v další ji zase charakterizuje „pocit jednoty, vzájemné tolerance, vědomí, že v duchu vzdorně získané spoluúčasti se snad může doufat v obrození něčeho nového - autentického, neodcizeného“.) Jako by autor tuto výtku předjímal, přiznává v autorské poznámce, že některá 
témata jsou zpracovávána opakovaně, stejně jako některé citace, které se znovu a znovu objevují. A ačkoli se prý snažil sérii studií takové textové nadbytečnosti zbavit a nahradit některé citace jinými podobnými, doznává nakonec: „ale brzy jsem to vzdal“ (s. 238). Spolu s autorem nijak nepopírám, že opakování jistých formulací přidávají na důležitosti jeho tezí; na druhou stranu by možná bylo vhodné nechat zaznít i hlasy jiných kritiků či literárních vědců stojících mimo underground, kteří by obraz učinili plastičtějším.

Autoritativnost Machovcova hlasu samozřejmě vyplývá už ze samotné povahy projektu, jenž byl zamýšlen jako dílo jediného autora, nikoli práce kolektivní. Posiluje se však zejména jeho proveniencí z undergroundového prostředí, a proto již zmiňované „mantrické“ formulace mohou vyvolávat dojem mytizace. Ostatně Jonathan Bolton přímo sebemytizaci, tendenci k vytváření mýtů o sobě samém, označuje za jeden z klíčových rysů undergroundové kultury. Nechci touto narážkou ani tak vytýkat autorovi jako spíš připomenout, že subjektivita vnesená do výkladu tak blízké historické doby může činit některá fakta relevantnější na úkor druhých, může upřednostnit to, co by jiný naopak upozadil, či s autorem vstoupil do polemiky.

Při hodnocení publikace jsem byla vedena otázkou, zda by mohla být opodstatněným příspěvkem jak k české, tak zahraniční literární historii (s ohledem na jejího čtenáře), a dále, zda a jaké nové literárněhistorické hodnoty autor svou knihou přináší. Jak jsem již výše doufám srozumitelně vyjádřila, publikaci Martina Machovce považuji za velmi přínosný a obohacující počin, $v$ tomto smyslu ojedinělý. Způsob, jakým se autor rozhodl čtenářskou, v užším smyslu zahraniční společnost o undergroundu „poučit“, se mi v kontextu deseti předložených studií jeví jako zdařilý a oprávněný. Martin Machovec bezesporu vnáší do literárně-historického pole nové postřehy a hodnoty, které mohly zůstat jak laické, tak odborné veřejnosti dosud skryty. Zmíněný nedostatek v podobě jediného převládajícího hlasu je vyvažován bohatým sumářem sekundární literatury a neméně hutnými odkazy pod čarou. Význam celého díla se nejspíše projeví až $\mathrm{s}$ časem, $\mathrm{v}$ referencích či polemikách, zkrátka v ustavování toho, co undergroundem budeme rozumět a zda dáme Martinu Machovcovi za pravdu. Tak či onak, předložená publikace se mi jeví hrdou velvyslankyní českého undergroundu. 